\title{
10
}

\section{EXPANSION AND CONSOLIDATION 1966-1976}

The first 10 years of the existence of Consolidated Gold Fields Australia (CGFA) from 1966 were marked by a combination of factors that saw the evolution of the portfolio that had been established in the early 1960s. These included the consolidation and expansion of key parts of the portfolio. In the case of Associated Minerals Consolidated (AMC) and the company's involvement in mineral sands, the aggregation of this company and Wyong Minerals occurred, while the acquisition of a majority shareholding in Western Titanium—a Western Australian-based mineral sands producerand further consolidation of smaller mineral sands companies were features of the period. The basis was also laid for the combination of AMC and Western Titanium, such that CGFA's mineral sands interests were conducted through one subsidiary from 1977. This consolidated the company's dominant position in mineral sands in Australia and on an international basis. The company's expansion into a new major mineral sands provinceEneabba in Western Australia — was a major achievement and, with this, the acquisition of one of the two other producers in the province. Technological developments led by Western Titanium resulted in the development of a process to upgrade ilmenite to a higher-grade titanium dioxide product, referred to as synthetic rutile.

In the case of Mount Lyell, Renison and Bellambi, further mine development and expansion plans were implemented that increased production. For the Mount Goldsworthy project, sales contracts were increased and with these annual production levels, through a move to 
new deposits, as well as exploration drilling that delineated a major new iron ore province. Acquisition opportunities were pursued, designed to add new businesses to the portfolio. An acquisition attempt was made for the tungsten producer King Island Scheelite, while a project to evaluate the potential acquisition of or merger with North Broken Hill was also undertaken. Neither eventuated, although smaller acquisitions were made, including an involvement in a Queensland copper project, Gunpowder, north of Mount Isa, which commenced production in 1972.

Diversification remained a part of the business strategy. Alumasc Holdings, majority owned by the London parent, became a subsidiary of CGFA after the acquisition of an Australian manufacturing company, Lawrenson Holdings. This added to the existing manufacturing involvement through the shareholding of Zip Holdings in New Zealand. Forays into property development occurred and agricultural and pastoral activities in New South Wales were undertaken through the establishment of a company, Colinas. Direct share investments in other mining companies continued, through subsidiary Circular Quay Holdings, which included Pancontinental Mining, North Broken Hill, Poseidon, Mount Isa Mines and a Western Australian mineral sands company, Westralian Sands. All can be considered investments in companies that represented potential acquisition opportunities. Pancontinental Mining was a key share investment for CGFA during the 1970s and again in the 1980s and would lead to a takeover in 1995 as part of a plan to separate the gold assets of Renison Goldfields Consolidated (RGC) and Pancontinental into a separately listed company.

Exploration remained a prime area of activity, as it did through the history of Gold Fields in Australia. It included consideration of nickel opportunities as well as a joint exploration arrangement with Lake View and Star. Oil interests were pursued, and although these did not amount to anything during this period, an investment in oil and gas was reconsidered in 1981. An agreement was concluded between Mount Lyell and Getty Oil Development Company in 1976 relating to exploration tenements in north-west Tasmania. This unincorporated joint venture ended by 1981, although with a subsequent association with Little River Goldfields in what became the Henty gold project.

The early years of the new, partially Australian-owned company were favourable, with improvement in the financial performance of investments and a strengthening financial profile in most years through to 1970 . 
In 1967, the pre-tax operating profit of the investments made by CGFA was $\$ 9.3$ million, which grew to \$27.6 million in 1970. In 1970 Mount Lyell contributed a profit before tax of $\$ 9.1$ million and Mount Goldsworthy $\$ 6.2$ million. Renison, as the world's largest producer of tin concentrate, generated \$3.5 million and AMC \$3.1 million, while Western Titanium contributed $\$ 1.4$ million. ${ }^{1}$ Given CGFA had a majority, but not outright control of most of its investments, this translated into an increase in attributable profit to CGFA shareholders from $\$ 4.1$ million to $\$ 12.3$ million over the period (see Appendix 4). CGFA and, in turn, its major shareholder, Consolidated Gold Fields, relied upon the dividends that flowed from its investments. In this regard, annual dividends over the period increased from $\$ 1.4$ million to $\$ 4$ million. The main parts of the portfolio remained copper, tin, iron ore and mineral sands, with manufacturing, share investmentsdirect and through Commonwealth Mining Investments (CMI) - and a smaller, residual holding in gold production through Lake View and Star.

Having invested $\$ 30$ million in establishing its position in Australia, the company was well placed to capitalise on existing assets by expansions and rationalisation, while also focused on capturing new business opportunities. The promising start to the new company was such that Sir George Harvie-Watt in his review of the 1968 year as group chairman stated 'Consolidated Gold Fields Australia has established itself as a major force in the mineral industry'. ${ }^{2}$ The success of the Australian subsidiary was measured in the context that CGFA's profits and market value were in 1968 larger than that of the entire Gold Fields group 10 years previously.

However, by the early 1970s, the performance of individual businesses, most notably Mount Goldsworthy, Gunpowder copper and Mount Lyell, as well as mineral sands, created financial challenges. Weaker export markets, increasing costs and, in the case of several parts of the business, protracted industrial disputes, contributed to weaker cash flows and earnings. The profile from 1970 until 1977 was one of a marked erosion in the financial performance of the business, due to prevailing global economic conditions and a decline in commodity prices, in some

1 Consolidated Gold Fields Australia, Fifth Annual Report 1971 and Notice of Meeting. The interests held by CGFA in 1971 were AMC, 61 per cent; Bellambi Coal, 67 per cent; Commonwealth Mining Investments, 60 per cent; Lawrenson Alumasc Holdings, 50 per cent; Mount Lyell Mining and Railway Company, 56 per cent; North-West Acid, 28 per cent; Renison 48 per cent; Western Titanium 81 per cent; Zip Holdings, 51 per cent. A one-third interest in the Mount Goldsworthy joint venture was also held.

2 Consolidated Gold Fields Limited, 'Chairman's Review 1968, Sir George Harvie-Watt'. 
cases magnified by the quality and operational performance of some operations. ${ }^{3}$ With a high level of capital expenditure, returns were not adequate and there was pressure on the liquidity and funding position of the company.

For the major London shareholder, the financial performance and prospects of its Australian subsidiary became of increasing concern. This led to various strategic options being canvassed by management and directors. A number of such considerations went to the heart of whether a diversified business model should be retained, or at least one where the major shareholder had little control over the cash flow, capital expenditure or ability to gain operational synergies across its various investments. The concept of 'divisionalisation' was considered, in effect the precursor to the 'Australianisation' process that occurred in 1981 when CGFA acquired outright control of its main subsidiary companies. In the meantime, cash flow pressures led to portfolio divestments, the most notable of which was CGFA's holding in the Mount Goldsworthy joint venture. Other investments were either ceased or, as in the case of the manufacturing businesses, put up for sale and sold between 1976 and 1978. Colinas and its agricultural activities and Bellambi Coal were considered for sale and a process commenced for each. It was a tumultuous time for the company, reflected in a developing lack of confidence by the London parent in Brian Massy-Greene in his role as managing director.

\section{Mount Lyell-the onset of challenges}

At the Mount Lyell operation at Queenstown in the second half of the 1960s, an extensive drilling program led to a 150 per cent increase in reserves and with this a major expansion project was planned, designed to increase copper output from 15,000 to 25,000 tons per annum. It was determined that additional ore of up to 45 million tons containing 1 per cent copper was obtainable in the Mount Lyell-Tharsis and Prince Lyell ore bodies. ${ }^{4}$ Exploration was designed to test the downward extension

3 Attributable profit to Consolidated Gold Fields Australia shareholders declined from $\$ 12.3$ million in 1970 to $\$ 2.8$ million in 1976 , before a loss of $\$ 11.1$ million in 1977 , including extraordinary items. The financial performance in the first half of the $1970 \mathrm{~s}$ was in the context of shareholder funds doubling from 1967 to 1977.

4 The Mount Lyell Mining \& Railway Company Limited, 'Directors' Report and Accounts and Chairman's Statement', 1964 and also the reports for 1965, 1966 and 1967, University of Melbourne Archives (UMA), Stock Exchange of Melbourne, 1968.0018, Unit 190. 
of the ore bodies to depths of at least 2,500 feet, more than double the depth of the ore body that had been accessed by the open cut mine. In 1967 Mount Lyell sent a study team overseas to examine the possibility of developing the ore body under the open pit. Consideration was also given to the construction of a smelter, either at Port Kembla or in Europe. Given the existing constraints upon housing an expanded workforce, Queenstown as a likely option for a new smelter was precluded from consideration. Mount Lyell management also had a desire to move away from the reliance on a contract with Electrolytic Refining and Smelting Company for the treatment of blister copper to an arrangement where concentrate could be sold to Japan with the benefit of a guaranteed floor price. Agreement was reached with Mitsubishi Metal Mining Company to purchase all of Mount Lyell's copper concentrate above the contractual obligation to Electrolytic Refining and Smelting. With this agreement and Commonwealth Government approval for the export of copper concentrate to Japan, the construction of a smelter, which had in any case been assessed as not economically viable, was no longer necessary.

Favourable copper prices contributed to an improved performance and in 1967 the profit earned by Mount Lyell was the highest in 74 years. By 1968, detailed studies determined the means to mine the Prince Lyell ore body by underground mining methods, progressively replacing reliance on the open pit, which was expected to be exhausted by 1972 . Development of the upper levels of the Prince Lyell ore body began in 1968. This was the precursor to the mining of a series of progressively deeper stopes, from the 10 series through to the 60 series, until the mine closed in 1994. The initial capital expenditure estimate for mining the underground ore body was $\$ 21$ million, although within a year this increased to $\$ 35$ million. Funding this expenditure occurred through a combination of bank debt, for which Mount Lyell's shareholding in Renison was part security, as well as an equity issue. CGFA itself undertook a rights issue in 1969 raising $\$ 8.6$ million, part of which repaid loans to Gold Fields Mining \& Industrial and part of which was used to strengthen the cash resources of the group for further investments, including that planned at Mount Lyell.

Pyrite as a by-product from Mount Lyell led to the decision to construct a sulphuric acid plant at Burnie, in partnership with EZ Industries, with the company North-West Acid formed in 1970. This proved to be a spectacularly unsuccessful investment, with innumerable commissioning issues, followed by a range of ongoing technical problems and production outages that meant that the operation did not meet its production 
capacity in any year. External factors, such as the sulphur price, removal of Tariff Board bounties and importation of superphosphate into Australia, impeded North-West Acid gaining improved prices. Losses were recorded in most years, with write-offs in carrying values and accumulated losses. In 1978, the main customer-ICI—advised that it did not wish to extend its contract beyond 30 June 1980. By this stage, with poor operational and financial performance, serious industrial disputation, the replacement of the operation's general manager and an inability of Mount Lyell to sell its interest, it was determined that production would cease. ${ }^{5}$

By 1972 mining from the underground section of the Prince Lyell ore body was contributing over 40 per cent of copper production. The West Lyell open cut ore body closed in September of that year. Copper prices between mid-1967 and 1971 were generally favourable. Profit for Mount Lyell peaked at $\$ 9.1$ million in 1970 , aided by the devaluation of the Australian dollar, compared to $\$ 890,000$ in 1965 , the year CGFA acquired a majority shareholding. Three leaner years followed, with large copper inventories, held by the London Metals Exchange and by customers in Japan, overshadowing the market and depressing prices. Mount Lyell's customer, Mitsubishi, sought a 25 per cent reduction in its contractual tonnages in 1971, although this was not agreed to. Concerted efforts were made to reduce costs, including by a reduction in the workforce. By 1974 market conditions had recovered temporarily, with record prices and copper sales leading to an operating profit of $\$ 12.4$ million. Copper prices peaked in April 1974 but then declined precipitously. With a world recession, copper demand contracted sharply at a time when increased supply had been incentivised by earlier higher prices. These factors, the operation's relatively high cost structure, as well as the major capital expenditure program implemented during 1968, eroded Mount Lyell's cash flow and created a serious financial situation. By 1975 Mount Lyell was facing severe financial challenges.

5 Copies of agenda papers for board meetings of North-West Acid Pty Ltd, 3 December 1969 15 December 1979, National Archives of Australia, Tasmania (NAAT), NS3244/1-5. I am grateful to Richard Knight who reviewed the chemical characteristics of the pyrite feedstocks from Mount Lyell and EZ Industries and suggested the respective chemical characteristics may have worked against their effective blending, with the EZ Industries' pyrite, from Roseberry, despite being slightly higher in sulphur, containing 'dirty elements', especially lead, zinc and arsenic (Richard Knight, personal communication, 6 February 2019). 
In 1974, the Mount Lyell directors had investigated the means to separate the mining and investment activities of the company, including its shareholding in Renison. This action was in response to a forecast estimated cash deficit for the 1976 financial year of $\$ 16$ million. Two methods were considered to address the financial circumstances: the extension of the company's loan facilities or the sale of the company's 44.5 per cent holding of Renison shares. The initial decision was to retain the Renison shares as they were viewed as a valuable long-term asset, not to be disposed of to resolve what was considered 'a short-term liquidity problem'. ${ }^{6}$ Bank cash facilities of $\$ 5$ million were increased to $\$ 10$ million with consideration of putting in place additional facilities of $\$ 16$ million. CGFA's requirement of the Mount Lyell directors for providing guarantees for part of these bank facilities was the development of a five-year plan for the operation. Various options were considered, including a commitment of essential capital expenditure only, placing the mine on care and maintenance, continuation of the development of the shaft or closing the mine.

The financial circumstances of Mount Lyell deteriorated, with a looming cash deficit of $\$ 24$ million. Gold Fields' commodities division in London further reduced its forecast copper price. If the forecast were to eventuate, Mount Lyell's overdraft requirements would climb to $\$ 28$ million in the second half of 1977, with little likelihood of additional bank financing becoming available nor CGFA being prepared to advance further funds. ${ }^{7}$ The serious financial situation was compounded by the mine's reduced output and lower grades, while production was also lost as a result of two fatal accidents in 1975. Meetings were held with the Commonwealth Government, where the company conveyed its inability to meet a tax instalment payment of $\$ 225,000$. The results of financial analysis tabled at a meeting with officers of the Department of Minerals and Energy made clear that Mount Lyell 'was rapidly going into a financial situation from which it may not recover'. 8

6 The Mount Lyell Mining and Railway Company Limited, 'Minutes of Meeting of Directors', 26 June 1975, p. 3, NAAT, NS3924/1/57, Items 90-102.

7 The Mount Lyell Mining and Railway Company Limited, 'Minutes of Meeting of Directors', 10 December 1975, p. 1, NAAT, NS3924/1/57, Items 103-115.

8 The Mount Lyell Mining and Railway Company Limited, 'Minutes of Meeting of Directors', 18 December 1975, p. 3, NAAT, NS3924/1/57, Items 103-115. 
Refinancing options were reconsidered by the Mount Lyell board, with a particular interest by the CGFA-appointed directors. Given the critical liquidity situation, it was considered appropriate to now sell Mount Lyell's shareholding in Renison. This decision was of major significance to CGFA. Mount Lyell's shareholding in Renison had been 'loosely pledged' to the company's bank as security against its loans and, as such, could be called upon by the banks for repayment of the outstanding loans. ${ }^{9}$ A forfeiture of the Renison shareholding would be a calamitous outcome for CGFA, since a major motivation for investing in Mount Lyell was the indirect interest it provided in Renison. Consolidated Gold Fields in London had become concerned with the fate of a major investment of its Australian subsidiary, not least because it also held a direct interest in Renison. Bart Ryan, the group's deputy chairman and deputy managing director, was dispatched from London to attend Mount Lyell board meetings. TF Lanz, an executive director of CGFA and a former general manager of Mount Lyell, as well as the general manager, DPC Sawyer, were summoned to London to provide detailed technical and financial information on the position and prospects of Mount Lyell.

In 1975, the decline in the copper price led to a loss from mining and processing operations, only offset by the company forward-selling a major part of its copper production at higher prices. A profit for the year of $\$ 2.2$ million was recorded. ${ }^{10}$ Despite the temporary financial reprieve, the concerns of the CGFA board and that of the London directors were growing. The June 1975 board minutes recorded: 'The Chairman noted that the company was in serious trouble and is incurring a heavy loss on present copper prices. The current cash deficiency is running at the rate of some $\$ 1.5$ million per month'. ${ }^{11}$ Later in the year, operational options were again canvassed. These included closure of the mine, cessation of all capital expenditure and mining out of existing reserves over an 18-month period, as well as ceasing mining but continuing with the capital expenditure program. ${ }^{12}$

9 Mount Lyell Copper Mine, 'Submission from Dept. of National Resources, Senate Select Committee', 26 November 1976, Renison Goldfields Consolidated Archives (RGCA), Box 746.

10 The loss from mining operations was $\$ 8.3$ million, with a profit from forward selling copper of $\$ 8.5$ million. Three years of losses followed and a barely break-even result in 1979 (The Mount Lyell Mining and Railway Company Limited, Annual Report 1975 and Notice of Meeting, p. 3).

11 Consolidated Gold Fields Australia Limited, 'Minutes of Meeting of Directors', 25 June 1975, p. 2, RGCA, Box 12246, RGC 11588.

12 Consolidated Gold Fields Australia Limited, 'Minutes of Meeting of Directors', 26 November 1975, p. 2 and 'Minutes of Meeting of Directors', 17 December 1975, pp. 4-5, RGCA, Box 12246, RGC 11588. 
A restriction of $\$ 500,000$ on capital expenditure was imposed by CGFA on the Mount Lyell board and management. The sale of the Renison shares, as well as a Mount Lyell's holding of ICI shares, proceeded, an action that was viewed externally to the company as a 'desperate bid to allow ... [it] to survive'. As Massy-Greene explained: 'The question we have had to face is how we should try to keep the company going for the time being.' ${ }^{13}$ Upon the sale of Mount Lyell's shareholding in Renison, CGFA acquired its entitlement, as well as the shortfall in uptake by other shareholders. Given its 56 per cent holding in Mount Lyell and its 31 per cent direct holding in Renison, CGFA held an effective 46 per cent shareholding in Renison. This increased after the Renison shares sale process; an outcome that was criticised by some within the Commonwealth Government as a deliberate means of enabling CGFA, as an overseas company, to gain greater control of Renison.

For the CGFA board, the parlous situation for Mount Lyell was compounded, in a portfolio sense, by the 'very depressing' iron ore outlook; Bellambi Coal suffering serious industrial disputes and a loss for the year; and the necessity to accelerate plans to double copper production from the Gunpowder project in Queensland to attempt to improve the operational efficiency and financial performance of this recently acquired but poorly performing operation. ${ }^{14}$ Consideration was given to the sale of Bellambi Coal as well as other assets. However, the sale of CGFA's investments, at a time of depressed mineral markets, in itself created a conundrum, recognised by Donald McCall, the London chairman. The situation available to the group was to sell income-generating assets, which were needed, or attempt to sell assets that were generating losses and, therefore, not readily saleable. ${ }^{15}$ The situation facing CGFA's portfolio would provoke a fundamental reassessment of the nature and structure of the Australian company's holdings.

By early 1976, the board of Mount Lyell believed that it had no option but to cease production unless government financial assistance was forthcoming. In effect, the increased reliance on underground mining sustained production levels, although with increased unit operating costs, in an environment of adverse exchange rates and rampant cost inflation.

13 The Age, 17 February 1976.

14 Consolidated Gold Fields Australia Limited, 'Minutes of Meeting of Directors', 26 November 1975, p. 3, 17 December 1975, p. 5 and 27 August 1975, p. 3, RGCA, Box 12246, RGC 11588.

15 Consolidated Gold Fields Australia Limited, 'Minutes of Meeting of Directors', 26 February 1976, RGCA, Box 12246, RGC 11588. 
As such, the financial performance of the operation remained highly sensitive to the copper price. The capital expenditure program of $\$ 32$ million for the Prince Lyell shaft subsequently increased to $\$ 45$ million by 1976, in part reflecting adverse inflationary effects with inflation at over 13 per cent. It was estimated that an additional $\$ 11$ million was required for completion of the number one shaft and underground crushing station. By October 1976, the price of copper fell further in world markets, adversely affected by the depreciation of the pound sterling. In the context of this rapidly deteriorating financial situation, revised copper price forecasts from London determined that the trigger price at which the contingency plan to close the mine would be activated was close to being reached. ${ }^{16}$ Instead, it was decided to continue copper production but postpone the remaining capital expenditure and retrench 38 employees and have another 25 employees take early retirement.

During 1976, Charles Copeman, an executive of CGFA, was appointed chairman of Mount Lyell, taking over from Massy-Greene. He recalled in later life that his directions from London were to close the Mount Lyell operation. Instead, a modified mining plan that reduced the estimated economic life of the operation from 12 to six years was implemented. The work on this plan was already in train, under the initiative of Sawyer, the Mount Lyell general manager. Sawyer, tall, tough and direct, had been general manager of Renison and was moved to Mount Lyell. He was viewed as not having existing allegiances to management and the workforce at Queenstown and, as such, capable of implementing radical changes. The Prince Lyell Plan entailed a 40 per cent reduction in the workforce through the retrenchment of 450 employees. The milling operation was reduced from seven days to five days per week. It was expected that the plan would enable Mount Lyell 'to remain solvent on a cash basis', although not profitable. ${ }^{17}$ Ryan held the view at the time that the ultimate closure of the mine remained a possibility, although devaluation of the Australian dollar in November 1976 provided some respite for the operation. As part of the evaluation of operating settings for Mount Lyell, management was also pursuing the sale of its interest in North-West Acid. This operation had been suffering both production and

16 'Submission to the Senate Select Committee to Inquire into Mount Lyell Mining Operations', 18 November 1976, pp. 2-3, NAAT, NS3357/1/185.

17 The Mount Lyell Mining and Railway Company Limited, 'Minutes of Meeting of Directors', 28 October 1976, p. 3, NAAT, NS3924/1/57, Items 128-137. 
demand offtake issues, as well as the adverse effects of low sulphur prices. Approaches to ICI for it to purchase the Mount Lyell share elicited a lack of interest.

The seriousness of the situation facing Mount Lyell and the social and economic consequences of a reduction in employment levels in Queenstown and the surrounding townships led to the appointment of a Senate Select Committee. The committee began hearings in November 1976. Multiple submissions were received, including one from Professor Geoffrey Blainey of the University of Melbourne, author of the seminal work on the history of Mount Lyell. His submission encapsulated the core of the concern by government and trade unions: that the planned reduction in workforce could 'inflict on the local residents, and indirectly on the whole Tasmanian economy, a financial loss that would far outweigh the subsidies required to sustain the mine in the near future..$^{18}$ Following the Senate Select Committee hearings, the Commonwealth Government was asked to consider the introduction of a subsidy to support the Australian copper mining industry, a request referred to the Industries Assistance Commission. Subsidies to Mount Lyell were forthcoming. The operators of Emu Bay Railway were approached to achieve a reduction in freight rates, while Mitsubishi was asked to reduce its smelting charges; a request it was initially reluctant to accommodate while Mount Lyell was receiving government subsidies.

The company decided to extend the Mount Lyell Plan by continuing to mine in what was referred to as the 'A' lens and at Cape Horn and Prince Lyell, but defer the remaining capital expenditure for the installation of underground crushing facilities and new locomotives for the deepening of the Prince Lyell shaft. This revision to the plan became known as the Prince Lyell Extended Plan. It was approved by the Mount Lyell board in December 1976, in the context of a half-year loss of $\$ 5.7$ million. The new plan entailed a reduction in ore production from 2.2 million tons to 1.5 million tons, the introduction of a five-day working week, centralisation of mining activities and rationalisation of surface engineering activities, and reduction of the workforce from 1,100 to

18 Blainey, The Peaks of Lyell. Blainey's submission contained within Australian Senate, 'Report of the Senate Select Committee on Mount Lyell Mining Operations', 3 December 1976, p. 13, NAAT, NS3357/1/186. 
720 workers. ${ }^{19}$ A range of other initiatives were taken to reduce costs, while the Tasmanian Government was approached for the purchase of the company's interest in the Lake Margaret power station.

In effect, the Prince Lyell Extended Plan was a 'holding operation', designed to reduce the levels of operating loss and conserve cash while retaining the option of moving to the deeper ore horizons at Prince Lyell in the future. ${ }^{20}$ Not for the last time, the Mount Lyell workforce displayed a high level of cooperation and support for management initiatives. As the Senate Select Committee report stated:

The close identification with and involvement of the people of Queenstown in all aspects of community life coupled with the unique relationship with the Company and the community, industrially, socially and culturally, has induced a community spirit and understanding not readily found elsewhere. ${ }^{21}$

The acting general manager, RM (Dick) Patterson, advised employees in 1977 that their efforts had resulted in a 25 per cent reduction in operating costs, an improvement in the grade of ore recovered and a 12 per cent reduction in the cash break-even level. Mount Lyell was held within the RGC portfolio until 1994, the year after Mount Lyell celebrated a centenary of operation, when, as part of the company's copper division, a decision was made to close the operation.

\section{Renison-a key part of the portfolio}

Renison's performance in the CGFA portfolio was, in many respects, the inverse of that of Mount Lyell. Initial poor performance, with an improvement in mining and operations, meant that Renison not only moved from being an indirect holding through the Mount Lyell shareholding to a direct subsidiary of CGFA, but also the asset viewed

19 Mount Lyell board minutes indicate that 100 employees left voluntarily and 46 were retrenched (The Mount Lyell Mining and Railway Company Limited, 'Minutes of Meeting of Directors', 23 December 1976, p. 2, and 27 January 1977, NAAT, NS3924/1/57, Items 128-137).

20 The statement to employees was provided associated with the interim results for the 1977 financial year that showed a loss of $\$ 3.4$ million (NAAT, NS 3924/1/57, Items 147-157).

21 Australian Senate, 'Report of the Senate Select Committee on Mount Lyell Mining Operations', 3 December 1976, p. 13, NAAT, NS3357/1/186. 
as of the highest quality in the portfolio by the mid-1970s. The 1976 decision, borne of necessity, to sell Mount Lyell's shareholding in Renison enabled CGFA to increase its shareholding to 51.09 per cent. ${ }^{22}$

In 1963, Renison's available ore reserves increased 30 per cent to 4 million tons as a result of drilling and development work. In the following year plans were advanced to increase throughput by mining at depth in the Federal ore body and by increasing processing capacity by the construction of a new mill. The plans involved a two-phase expansion: an immediate increase in ore treatment capacity to 200 tons per day and a scheme to move to 1,000 tons per day within two years, with the potential for additional expansion. At an original estimate of $\$ 8$ million, the plans included additional housing for workers at Zeehan, along with the facilities at the mine site. Funding of the development occurred by a rights issue undertaken by Renison as well as a $\$ 2$ million loan advanced by CGFA, in return for later exercising an option to acquire 400,000 Renison shares. Those responsible for the planning and construction of the mill had experience with lead-zinc processing in Broken Hill, although not a tin operation. The commissioning of the mill operations occurred in December 1966. Initially, the fine cassiterite tin oxide, with its association with massive sulphide mineralisation, from the FederalBassett fault structure posed technical challenges for milling. The ore was hard, with the fine cassiterite crystals making separation of the tin difficult. Initially, recoveries were as low as 30 to 40 per cent, with operational challenges necessitating the need to develop a skilled workforce able to manage the complexities of ore feed and mill settings. Technical problems in commissioning the new treatment plant and higher depreciation levels for the old plant meant that after an investment of $\$ 9.5$ million, the company generated a meagre $\$ 40,000$ profit in the 1967 financial year. In 1968, the first full year of production from the Federal lode, low recoveries contributed to a loss of $\$ 910,000$, with no dividend payment.

The blending of the Federal-Bassett ore with a carbonate ore zone helped improve recoveries. Furthermore, considerable experimental work was undertaken on flotation of cassiterite from tin ores. The metallurgical team at Renison was supported by experts from Mitsubishi and the Freiberg Institute of Berlin, as well as by technical input from the Gold Fields group in Australia, the United Kingdom and South Africa. Mitsubishi, Renison's

22 Consolidated Gold Fields Australia Limited, Tenth Annual Report 1976 and Notice of Meeting, p. 6. 
principal customer, had undertaken research on tin flotation to maximise the recovery of tin from its own complex base-metal mine, Akenobe in Japan. Experimental work using Renison ore occurred in Japan and a pilot plant was constructed at Zeehan. ${ }^{23}$ Mitsubishi provided the reagent used at Renison. By 1969, the metallurgical issues encountered had been addressed through blending of the ore and installation of additional gravity separation equipment, while the trials for recovery of tin by the new flotation process proved encouraging. Tin in concentrate production doubled with a study in progress to increase ore treatment from 400,000 to 1 million tons per annum. By 1970, Renison had established itself as Australia's largest tin producer. The loss of the previous year was converted into an operating profit, with annual profits before tax climbing from $\$ 3.5$ million in 1970 to over $\$ 19$ million in 1977 , before rising to $\$ 47$ million in $1980 .{ }^{24}$

While other parts of the portfolio struggled financially in the mid-1970s, Renison represented the one shining light and, in 1977, was among the top twenty most profitable Australian companies. ${ }^{25}$ This was despite constraints on production associated with restrictions by the International Tin Council that, in 1975, imposed an 18 per cent reduction in Australian tin exports, at the stage when domestic consumption had declined. ${ }^{26}$ Renison represented an impressive, high-quality investment. It would centre in considerations by the CGFA board as to how the portfolio may be restructured, with one consideration being the divestment of all other investments while retaining a majority interest in Renison.

\section{Mount Goldsworthy—growing disenchantment}

CGFA's one-third holding in the Mount Goldsworthy joint venture was the initial centrepiece of the company's portfolio in Australia. In 1967, Ryan had been appointed general manager of Goldsworthy Mining, the operating company for the Mount Goldsworthy joint venture. His appointment was noteworthy in the context of later events; he became a director and deputy chairman of Consolidated Gold Fields in the United

23 Goodman and O'Keefe, 'Tin ore treatment at Renison Limited'.

24 The after-tax result for 1980 was $\$ 21.4$ million. See Appendix 4 .

25 Bambrick, Australian Minerals and Energy Policy, p. 8.

26 Consolidated Gold Fields Australia Limited, 'Minutes of Meeting of Directors', 25 June 1975, p. 2, RGCA, Box 12246, RGC 11588. 
Kingdom and from 1976 managing director of CGFA. He would also be one of the key individuals responsible for CGFA's decision, and that of the London parent, to divest the holding in the Mount Goldsworthy joint venture.

In 1966 first production commenced, with Mount Goldsworthy's profit of $\$ 1.1$ million in that year representing over a quarter of the group's total. Sales volumes grew progressively, with the one millionth ton of iron ore shipped in January 1967. In June of that year an agreement was reached with a consortium of Japanese steel mills to supply a further 3.25 million tons of iron ore fines in addition to the 16.5 million tons of lump ore already contracted. Trial shipments were underway to European customers, with plans to expand annual production by the development of additional deposits to the north-east at Shay Gap and Kennedy Gap. In June 1968 the Mount Goldsworthy joint venture concluded an additional sales contract for 10 million tons of iron ore to Japanese steel mills over 10 years beginning in October 1969. ${ }^{27}$ By 1969, expansion plans were being progressed to increase Mount Goldsworthy production to 8 million tons per annum, with ore sourced from Mount Goldsworthy, Shay Gap and Kennedy Gap.

As part of Harvie-Watt's chairman's address to the 1968 Consolidated Gold Fields group annual general meeting in London, he referred to the 'outstanding item of interest' in Australia as the 'continuing progress ... at Mount Goldsworthy'. ${ }^{28}$ By the early 1970s contracts were in place for 60 million tons of lump and fine. CGFA's share of profit in 1970 increased to $\$ 7.1$ million of which $\$ 6.2$ million was incorporated into CGFA group accounts. By 1971 the move to the new deposit at Shay Gap was underway, enabling the increase of production to 8 million tons per annum from 6.8 million tons.

Mount Goldsworthy Mining Associates undertook an evaluation of another iron ore deposit on its tenements, Mining Area C. In 1970, an exploration program was undertaken of this temporary reserve, encompassing an area of 1,100 square kilometres. Exploration identified a major resource, estimated at over 700 million tons of high-grade Marra

27 The two contracts included one for 10 million tons over 10 years, made up of lump ore and fines and another for just over 1 million tons of fines for a five-year period (The Canberra Times, 15 October 1968).

28 Consolidated Gold Fields Limited, 'Chairman’s Review 1968, Sir George Harvie-Watt'. 
Mamba ore, an ore that had not to that stage been produced in Western Australia. The joint venture partners proceeded with a preliminary feasibility study, which was completed in 1973.

The interest in iron ore in Western Australia was also associated with CGFA, Cyprus Mines Corporation and Utah Construction \& Mining Co. acquiring an option in 1970 to take an interest in a joint venture to evaluate the potential development of temporary reserves controlled by Hancock Prospecting and Wright Prospecting (Hanwright). These included deposits known as McCamey's Monster and the Western Ridge iron ore deposits. By 1972, with Mining Area C as a potential deposit to be developed, the CGFA board recognised that it had, in effect, a conflict of interest between its consideration of Mining Area $\mathrm{C}$ and that for the development of McCamey's Monster. This led to a consideration for the extension of the period of withdrawal from the McCamey joint venture to allow evaluation of the Mining Area $\mathrm{C}$ deposits to continue. As it transpired, the McCamey's deposit was acquired by BHP and developed in 1993 as the Jimblebar deposit.

From 1972, CGFA's future involvement in iron ore came under intense scrutiny. The factors that caused a decline in the attraction of the sector for CGFA were multifaceted. They included a severe downturn in the Japanese steel industry, the adverse impact on shipments associated with a prolonged Japanese seaman's strike, the devaluation of the United States dollar and further revaluation of the Australian dollar, as well as increasing operating costs and an increased level of industrial disputes at the mining operations. A serious decline in sales levels and profitability occurred, at a time when the mining expansion at Shay Gap, for which a new township had been constructed, was underway and when a decision for a major capital commitment for Mining Area C was imminent. ${ }^{29}$ In 1973, associated with reduced sales and higher operating costs, accumulated profits from Mount Goldsworthy Mining Associates were drawn upon to allow a $\$ 4.3$ million reported profit for CGFA: lower than the previous year's $\$ 5.7$ million. The effects of the constraints upon the Japanese steel industry became apparent, with increased operating costs and a 'constant escalation in salaries and wages' for Mount Goldsworthy

29 The development of the township of Shay Gap, 60 kilometres from Goldsworthy, involved a radical concept in housing styles. The architect, Lawrence Howroyd, designed houses in clusters with central air conditioning facilities, cables buried underground and traffic banned from the central parts of the township. As Howroyd explained, his design sought to 'remove the wide and frightening horizon' (Film Australia, Living Way Out, 1977, wanowandthen.com/Shay-Gap.html). 
adversely affecting the operation. ${ }^{30}$ In 1974 , the devaluation of the United States dollar and lost production due to industrial disputes meant that the financial contribution of Mount Goldsworthy was \$236,000-an uninspiring outcome at the peak stage of capital commitment and with the necessity for further large sums to be expended if production was to be increased through the development of Mining Area C.

In 1975, the financial contribution had improved, due to higher shipments, higher prices negotiated in 1974 with Japanese customers and a devaluation of the Australian dollar. However, these benefits were largely offset by a further escalation of costs, a higher waste-to-ore ratio at the mines-particularly at Mount Goldsworthy_as well as poor equipment performance reliability, due in part to the difficulty of recruiting and retaining skilled operational and maintenance personnel. A financial contribution to CGFA of $\$ 1.3$ million was recorded. Worse was yet to come. The escalation of costs in 1976 by over 26 per cent, along with reduced shipments, resulted in a loss for CGFA from Mount Goldsworthy of $\$ 2.3$ million. This loss was partially mitigated by a further drawdown on reserves, with a loss of just under $\$ 2$ million recorded. ${ }^{31}$ By this stage CGFA's disenchantment with iron ore was almost complete.

Massy-Greene advised the president of the Nippon Steel Company of the challenges facing Mount Goldsworthy at a meeting in Melbourne in 1974 prior to the commencement of the annual price negotiation. He recorded:

I spoke of Goldsworthy's present and future position emphasising that the increasing reduction in profitability of our iron ore undertaking is a matter of great concern to the joint venture companies and their shareholders. I emphasised that the financial return on our investment was inadequate and I made some general observations about the need for a considerably better return on the investment so as to ensure the availability of capital for the development of existing and new mines and laid particular stress on the need for better prices to justify the development of new areas. $^{32}$

30 Consolidated Gold Fields Australia Limited, Sixth Annual Report 1972 and Notice of Meeting, p. 2.

31 For the 1976 financial year, the year that the sale of Mount Goldsworthy occurred, the loss incurred by Consolidated Gold Fields Australia was a further $\$ 2$ million (Consolidated Gold Fields Australia Limited, Eleventh Annual Report 1977 and Notice of Meeting, p. 6).

32 Telex Massy-Greene, 3 July 1974, RGCA, 6616, Box 12612. 
The response from the customer representative was not encouraging. As Massy-Greene recorded, it related to 'the usual treatment of how badly the steel industry faired in recent times' and its lack of profitability. ${ }^{33}$

Pricing and contractual arrangements required the involvement of the Commonwealth Government, a matter that consumed considerable management and board time. The Australian iron industry participants were under direction from Canberra that any pricing arrangement had to be submitted to the Department of Minerals and Energy. Reflecting the often-varying approaches of the industry participants to pricing outcomes, one of the Mount Goldsworthy joint venture partners observed to Massy-Greene:

In all of this we find it ironic, but nonetheless gratifying that Australian producer solidarity stems in large measure from pressures by the Whitlam Government and especially from its chief bere [sic] noir, F. X. Connor. However distasteful the pressures and interference, they seem a welcome contrast to those early days when Hamersley and Mt. Newman were dying to see who could make the greatest price concessions. ${ }^{34}$

Price negotiations with the Japanese steel mills proceeded over July and August 1974. Mount Goldsworthy sought a 35 per cent increase in line with that sought by Hamersley. These efforts were undercut by Mt Newman which sought a 25 per cent increase and then a 7.5 per cent increase the following year. ${ }^{35}$ The 'brevity' of a crucial meeting of the marketing representatives for Mount Goldsworthy with the head of the delegation for the Japanese steel mills was viewed as an 'unwillingness [by the Japanese steel mills] to discuss further any proposal for a 35PCT [35 per cent] increase, or equivalent US DLR [dollar] flat rate', with the objective to secure Mount Goldsworthy's agreement to the Mt Newman agreement for use 'as a lever against Hamersley'. ${ }^{36}$

A Utah representative expressed his lack of satisfaction with the negotiating abilities of Marcona on behalf of the Mount Goldsworthy joint venture:

33 ibid.

34 Telex Allen, Cyprus for Massy-Greene, 3 June 1974, RGCA, 6616, Box 12612.

35 Telex Kober, 10 July 1974, RGCA, 6616, Box 12612.

36 Telex S Iki Vice President, Marcona for Allen/Massy-Greene/Wallace, 17 July 1974, RGCA, 6616, Box 12612. 
The negotiating effort ... must be one of the most ineffectual on record, ultimately consisting of 'me too' reactions to agreements reached by others. We believe this was a totally inappropriate and unnecessary posture for Goldsworthy to assume ... Unfortunately, Mr. Connor may have been correct when he called us hillbillies. ${ }^{37}$

CGFA shared Utah's disquiet and was instrumental in having Marcona replaced as the marketing arm for Mount Goldsworthy.

A meeting followed of all the iron ore producers with Lennox Hewitt, Secretary of the Department of Minerals and Energy, and the minister, Rex Connor. Both were underwhelmed by the then agreed 20 per cent price increase. Hewitt indicated he was expecting a 25 per cent increase and a further 7.5 per cent for other contractual arrangements under review, while Connor emphasised the importance of iron ore as a source of export income and made his expectation clear that a 30 per cent increase should be sought, advising the participants to 'go back to the mills as soon as possible to achieve this' ${ }^{38}$

Consideration of the development of the Mining Area $\mathrm{C}$ deposit was in the context that the Mount Goldsworthy joint venture believed it would not be able to fulfil its contractual requirements from the Goldsworthy, Shay Gap and Sunrise Hill deposits without the further development of other deposits, such as Nimingarra and Kennedy Gap. Development of the much larger Mining Area $\mathrm{C}$ deposit was viewed as a more efficient approach than developing multiple, smaller areas. As such, the progressive development of Mining Area C was envisaged from mid-1978 through to 1981. Mining Area C's entry to the market was dependent, however, on global demand for steel that, given the state of the Japanese steel industry, was near impossible to forecast. Complicating the situation further was the likely commencement of new iron ore production from the Ivory Coast and Brazil. Despite technical presentations to the Japanese steel mills in 1973 and the supply of lump iron ore samples, the Japanese customers suspended consideration of Mining Area $\mathrm{C}$ and other deposits due to their inability to forecast future demand in the face of uncertainty for steel demand. ${ }^{39}$ By October 1974 an updated Mining Area C feasibility study had been completed. While the financial returns were acceptable it was the view of the joint venture that if development were to proceed

37 Telex Wallace for Kober, 24 July 1974, RGCA, 6616, Box 12612.

38 Telex for Allen/Massy-Greene/Wallace/Bilhorn, August 1974, RGCA, 6616, Box 12612.

39 Telex Kober to Allen/Massy-Greene/Wallace, 10 September1974, RGCA, 6616, Box 12612. 
it would have to occur quickly; to defer a decision would make the project economics vulnerable to an escalation of costs, estimated to be at least 10 per cent annually.

In 1975, an internal review by CGFA of the Mining Area C project took place. The deposits then being mined-Mount Goldsworthy, Shay Gap and Sunrise Hill-were expected to be exhausted by 1979 . The smaller deposits were considered to not justify investment. As such, it was concluded:

Any long term future of Goldsworthy therefore, is seen to attach to the reserves of Mining Area ' $\mathrm{C}$ ' (MAC) and the effort has been directed at the development of the MAC Marra Mamba reserves. These amount to some 700 M.T. [million tons] of 'geological' reserves in the whole of Area 'C', with an approximate 280 M.T. of 'mineable' reserves. ${ }^{40}$

Mount Isa Mines had been invited to take equity in the Mount Goldsworthy project, in order to increase total Australian participation. A concept considered by CGFA, although not pursued, was that once Mount Isa Mines entered the joint venture, CGFA's 25 per cent interest in Mount Goldsworthy could be transferred to a public company and listed on the Australian stock exchange. The new entity was contemplated to include a shareholding by the Japanese steel mills to reinforce their commitment to the development of Mining Area C. ${ }^{41}$

CGFA's consideration of its options for continued involvement in Mount Goldsworthy was made in the context of the financial performance and growth prospects of the overall CGFA portfolio. These included the likely need for major investment in mineral sands, with the Eneabba project in Western Australia undergoing detailed examination during 1974. High interest rates and associated issues with funding projects weighed heavily on board deliberations. Directors remained concerned and unconvinced about the merit of continued involvement in iron ore. In 1974, the views of the managing director and chairman of CGFA were summarised as follows:

40 Consolidated Gold Fields Australia Limited, “MAC” Project Review', p. 1, RGCA, 9286, Box 12301.

41 ibid., p. 67. 
The incremental effect on annual profit of C.G.F.A. is minimal despite the increased capital requirements ... [with] large developments and cash requirements ... required in future to open up not only the smaller reserves in the north but Mining Area ' $\mathrm{C}$ ' to the south. [He] summarized the position by stating that the decision must now be made as to whether C.G.F.A. continues to develop its interests along with its co-venturers in the expansion of iron ore operations or just allows its present operations to continue at some 8,000,000 tonnes per annum and face up to future requirements as and when they come along. ${ }^{42}$

CGFA's perspectives were also influenced by the 'chaotic' industrial situation associated with the iron ore operations, with a view of the CGFA board that the joint venture should 'stand firm ... against industrial blackmail' by the unions. ${ }^{43}$ A CGFA director also lamented the 'Government's failure, after more than 10 months in office, to enunciate its resources policy in clear terms'. ${ }^{44}$ The deteriorating financial performance in the 1970 s meant that an increase in export prices became an imperative. In 1975, a joint venture delegation to Japan sought a 39 per cent increase in iron ore prices, at a meeting with the steelproducing customers. A report following the visit conveyed that the 'Japanese were very depressed and were adopting the position that there was no prospect whatsoever of any price increase at the present time'. ${ }^{45}$ This, the likely need for further Australian participation in the ownership of Mount Goldsworthy, as well as the straitened cash position of CGFA, weighed upon board deliberations. A decision on the company's commitment to Mining Area $\mathrm{C}$ was required by 1976 . The orientation of the board was not to be involved in the Mining Area $\mathrm{C}$ development, given the level of capital expenditure and the limited likelihood of securing a contractual offtake from customers at materially higher prices than those prevailing. As will be conveyed in the next chapter, the future of Mount Goldsworthy in the CGFA portfolio was a matter of intense consideration during 1976.

42 Consolidated Gold Fields Australia Limited, 'Minutes of Meeting of Directors', 23 January 1974, p. 4, RGCA, Box 12264.

43 Consolidated Gold Fields Australia Limited, 'Minutes of Meeting of Directors', 24 April 1974, p. 3, RGCA, Box 12264.

44 Consolidated Gold Fields Australia Limited, Seventh Annual Report 1973 and Notice of Meeting, p. 5.

45 Consolidated Gold Fields Australia Limited, 'Minutes of Meeting of Directors', 28 January 1976, p. 9, RGCA, Box 12246, RGC 11588. 


\section{Bellambi-mixed fortunes}

The investment in Bellambi Coal offered mixed fortunes for CGFA. As with iron ore, industrial disputes, as well as a burdensome regulatory environment in terms of duties and other financial imposts, added to the complexities of the business. After a 1965 arrangement with the Japanese steel mills and other customers for the supply of 1.25 million tons for three years, by 1969 arrangements were in place for the delivery of 6.3 million tons over a five-year period to 1974. Arrangements for a further 7.5 million tons were subsequently secured. The contracts delivered revenues of $\$ 150$ million. This was sufficiently attractive for an expansion program to open up a further seam at South Bulli and install two additional long-wall mining units. ${ }^{46}$

In 1967, technical issues with the implementation of a long-wall unit led to production outages that resulted in the Japanese customers deferring the commencement of the new contract for a year; a level of accommodation that was a feature of the relationship by Bellambi's main Japanese customers, notwithstanding frequent production disruptions. Despite geological and ongoing technical challenges, the long-wall unit contributed to higher production and a second continuous longwall miner was in operation by January 1969. In that year a new sales contract with Japanese customers was finalised with a higher selling price agreed. ${ }^{47}$ In 1970, production output was adversely affected by industrial unrest in the Illawarra region arising from union demands for a shorter working week. Despite the prior year investments, Bellambi suffered a major decline in profits in 1970. Profits halved from 1969 as a result of a combination of difficult mining conditions, a delay in obtaining replacement parts for one of the long-wall mining units and the idling of mining operations for 10 days due to strike action. ${ }^{48}$ In 1970 Corrimal Coke was purchased, expanding Bellambi's existing coke facilities. While this contributed to a 150 per cent increase in coke sales in 1971, it was a relatively minor part of overall revenues.

46 Consolidated Gold Fields Australia Limited, Third Annual Report 1969 and Notice of Meeting, p. 19.

47 The Bellambi Coal Company Limited, 81st Annual Report and Notice of Meeting, Year Ended June

30, 1969 , p. 4.

48 The Bellambi Coal Company Limited, 82nd Annual Report and Notice of Meeting, Year Ended June 30, 1970, p. 3. 
In the early 1970s, the recession in the Japanese steel industry reduced steel production levels, a factor also evident in the performance of CGFA's involvement in the supply of iron ore through the Mount Goldsworthy joint venture. The global context also included an emerging currency crisis with the United States' decision to cancel the direct international convertibility of the United States dollar to gold, and its implications for the devaluation of this currency. Massy-Greene expressed little concern in relation to the implications for Bellambi and, in terms of the performances from 1971 to 1973 , his view was justified. He believed the reduction in steel production would not have an effect on coking coal sales unless there was a reduction in pig iron production. Furthermore, the contracts with Japanese customers were expressed in sterling with the opportunity for 'additional corrective measures for both buyer and seller in the event of a revaluation or devaluation of the currency'. ${ }^{49}$ The Japanese buyers proved to be reliable consumers of coal, although as Japanese stocks of imported coal increased from already high levels as steel capacity reduced, additional markets for Bellambi coal were sought, including in Europe, as well as the establishment of contracts in Taiwan, South Korea and China.

Industrial disputes continued to be a feature of the New South Wales coal fields. Production from one of the company's coal-washing production facilities, Federal Coke Works, was suspended in November 1971 while shipments of coal were adversely affected by the All-Japan shipping strike. Notwithstanding these factors, the 1971 net profit after tax was $\$ 320,952$, a record for the company. Despite this, the Bellambi board was concerned that the company's investment and increase in its workforce by 18 per cent had delivered only a 2 per cent production increase. Massy-Greene, chairman of Bellambi, warned that the 'unit cost of production had increased at an "alarming rate" in the context of broader challenges brought about by a world currency crisis and recession in the Japanese economy'. ${ }^{50}$

The environment was also one of continuing challenging geological conditions and equipment reliability issues. The operation was also affected by industry-wide union actions, including the progressive reduction in working hours from 40 to 35 and agitation for increased wages.

49 The Bellambi Coal Company Limited, 'Address by Chairman: JB Massy-Greene', in '83rd Annual Meeting', 24 September 1971, p. 2.

50 The Bellambi Coal Company Limited, 83rd Annual Report and Notice of Meeting, Year Ended June 30, 1971, p. 4; The Bellambi Coal Company Limited, 'Address by Chairman: JB Massy-Greene', in '83rd Annual Meeting', 24 September 1971, pp. 1-2. 
Associated with increased regulatory requirements, there was a need to commit additional capital expenditure to comply with pollution measures related to the company's coking coal facilities. Notwithstanding these factors, the company's investment in mechanised long-wall equipment and an expansion of the workforce resulted in coal production increasing by 22 per cent in 1972 and a further 14 per cent in 1973. Profitability in both years increased to over $\$ 400,000 .^{51}$

Bellambi's favourable financial performance came to a jarring holt in the 1974 financial year. The company recorded its first loss in 50 years, despite the 1973 financial year performance being the second highest on record. While a dividend continued to be paid, the reasons for the financial decline were conveyed starkly:

The predominant cause of the loss was industrial action taken by the company's employees as part of a nationwide campaign by all the mining unions. This expressed itself in the form of strikes, bans and other disruptions to production, all designed to force the company to comply with the Union's demands for higher wages and other benefits. 52

Over 100 days were lost at the coke works and 20 days at the colliery operations. Coal production for the full year declined by 19 per cent, and coal sales were 16 per cent lower. A retrospective element in two employment awards meant that $\$ 355,000$ in additional costs were incurred. The loss after tax for the year was $\$ 639,796 . .^{53}$ The only saving grace was securing a further contract for an additional 6 million tonnes of coal to be supplied over five years and a substantial increase in price that, in the view of the company, 'more appropriately related to contract export prices charged by other countries after adjustment ... for quality differentials'. ${ }^{54}$ Largely as a result of the renegotiated sales price, Bellambi returned to profit in 1975 , with a record net operating profit of $\$ 1.2$ million, achieved despite lower coal sales. In June 1975 the company warned of a 'dramatic worsening of the industrial situation'. ${ }^{55}$ As a consequence of industrial

51 The Bellambi Coal Company Limited, 84th Annual Report and Notice of Meeting, Year Ended June 30, 1972, p. 4; The Bellambi Coal Company Limited, 85th Annual Report and Notice of Meeting, Year Ended June 30, 1973, p. 6.

52 The Bellambi Coal Company Limited, 86th Annual Report and Notice of Meeting, Year Ended June 30, 1974, p. 8.

53 ibid., pp. 8 and 9.

54 The Bellambi Coal Company Limited, 87th Annual Report and Notice of Meeting, Year Ended June 30, 1975, p. 6.

55 ibid. 
action, the company was unable to conduct parts of its mining operation in an efficient manner, and notices of termination of employment were issued to 899 employees in August 1975.

Charles Copeman was appointed chairman of Bellambi in 1975. In the context of his later role as managing director at Peko-Wallsend in reforming what were considered disruptive work practices and in improving the productivity of that company's Pilbara iron ore operations, the industrial challenges he tackled at Bellambi were influential in informing his subsequent management approach. ${ }^{56} \mathrm{He}$ expressed the company's concerns in public forums, highlighting a myriad of government imposts and constraints, as well as identifying an industrial relations environment antithetical to company profitability. Not least, Copeman expressed his concerns with the Commonwealth Labor Government, observing:

The consequences of the intervention by the Minister for Minerals and Energy of the Australian Government, The Hon. R.F.X Connor, in the negotiations between the company and its Japanese steel mill customers. By creating the precedent for direct Government intervention, the future basis for negotiations between the commercial parties must now be uncertain. ${ }^{57}$

The 1975 Commonwealth budget included the introduction of a coal export duty of $\$ 6$ per tonne, with undertakings sought from coal companies that they would not seek to recover this duty on pain of export approvals being refused. Requirements to comply with the New South Wales Clean Air Act, for which the company had spent over $\$ 1.2$ million, and the uncertainty associated with the outcome of a New South Wales Government commission of enquiry into whether mining would be permitted in the vicinity of stored waters, added to the concerns held by directors of CGFA about the investment in Bellambi. ${ }^{58}$ The company's financial reporting typically began by detailing the level of operating income generated and then the amount paid to various levels of governments through duties, income tax, coal royalty, payroll tax and levies. These payments often constituted 80 per cent of operating expenses.

56 Michael Copeman, 'Vale Charles Copeman, Hero of Robe River', Quadrant Online, 11 July 2013, quadrant.org.au/opinion/qed/2013/07/vale-charles-copeman/.

57 The Bellambi Coal Company Limited, 87th Annual Report and Notice of Meeting, Year Ended June 30, 1975, p. 7.

58 ibid. 
In 1976, Bellambi achieved a markedly increased price for its coal sales, reflecting the renegotiation of prices to international levels. The following year marked the high point of CGFA's financial involvement in Bellambi, with a net profit in the 1977 financial year of $\$ 5$ million, compared to $\$ 1.3$ million in 1976 and $\$ 220,000$ in 1964 , the first year of CGFA's involvement. Coal sales exceeded 940,000 tonnes compared with 580,000 tonnes the previous year, while new contracts were signed with Chinese and Taiwanese customers. ${ }^{59}$ Two years later in 1979, despite coal production reaching 1.1 million tonnes, an operating loss of $\$ 367,000$ was recorded. Industrial disputes at Port Kembla during March and April 1979 meant that all deliveries to customers ceased and the company again sought approval to stand down employees. Payments to governments in the year exceeded the company's total operating revenues, with an additional impost - a recently introduced transport coordination levy-adding to the existing charges, along with demurrage costs incurred associated with port congestion and industrial disputation at Port Kembla.

Further issues relating to government policy settings created uncertainty. The New South Wales Government asked Bellambi to cease road transport of coal to Port Kembla and instead use rail transport. For the operation this entailed an additional $\$ 11$ million in expenditure and higher freight charges. Copeman wrote to the New South Wales deputy premier:

It has been with the greatest concern that I have put to you and your ministerial colleagues recently the financial position of this company. The effect of one setback after another has not only put the company into a loss, but it has created a situation in which no investor could be expected to be willing to commit further vitallyneeded capital funds to maintain the company's production capacity, without a clear prospect of the company being able to return to strong profitability ... The destruction of investor confidence has had a very serious effect, not only on financial matters, but much more importantly in my view, on the morale of the Bellambi work force. ${ }^{60}$

59 The Bellambi Coal Company Limited, 89th Annual Report and Notice of Meeting, Year Ended June 30, 1977, p. 4.

60 Letter from Charles Copeman, chairman, Bellambi Coal Company Limited to The Hon LJ Ferguson, 14 August 1979, pp. 1-2. 
Furthermore, the company was no closer to gaining clarification as to whether approvals would be forthcoming from the state government for mining in areas for which applications had been lodged. The situation was close to calamitous. As Copeman stated at the 1979 Bellambi Coal annual general meeting:

This most disappointing result illustrates the way in which a fundamentally profitable trading enterprise can be rendered unprofitable by events beyond the influence of the Company. I refer of course to the need to meet government imposts which take no account of the financial conditions of the enterprise, and to the crippling industrial actions ... at Port Kembla. ${ }^{61}$

The prospects were bleak, not least because from April 1979 the company was forced to accept a reduction in its selling price for the next two years, with no ability to achieve any price escalation to match cost increases. ${ }^{62}$

CGFA, as its major shareholder, had contributed to Bellambi achieving higher levels of production and increased profitability in large measure through a major investment in the adoption of mechanised mining. As Copeman conveyed in 1978: 'As a technical achievement it [mechanised long-wall mining] has been of the highest order of merit, and without it [the] Company would have been financially moribund'. ${ }^{63}$ In the first half of the 1970s, in the context of the circumstances confronting CGFA with problems related to Mount Lyell, Gunpowder and Mount Goldsworthy, consideration was given to the sale of Bellambi. This had come to the fore with the poor 1975 result, although the decision was forestalled by the ability of Bellambi to improve its performance. However, by 1978, fundamental challenges were evident relating to CGFA's ongoing investment in Bellambi, associated with gaining access to new deposits to extend mining operations and maintain production. Such outcomes were dependent on the New South Wales Government granting approvals, an outcome in which the directors had little confidence.

After an extended period during which the company had increased production, improved production efficiencies and diversified markets, the prospects, as Copeman conveyed, were for a 'period of severe cost

61 The Bellambi Coal Company Limited, 'Address by Chairman: Mr AC Copeman', in '91st Annual Meeting', 25 September 1979, p. 1.

62 ibid., p. 2.

63 The Bellambi Coal Company Limited, 'Address by Chairman: Mr AC Copeman', in '90th Annual Meeting', 26 September 1978, p. 3. 
price squeeze, exacerbated by shipping difficulties ... which ... have left their mark in the form of increased charges and the risk of loss of buyer confidence. ${ }^{64}$ The investment in Bellambi Coal was retained until 1979, when sold. Bellambi was to be a forerunner to another, more protracted planned entry into New South Wales coal; this time in association with Dalgety in the Hunter Valley.

\section{Mineral Sands-multiple strands}

CGFA's mineral sands portfolio had two main components. One was the east-coast operations centred upon the activities of Associated Minerals Consolidated (AMC) and the other the Western Australian operations based upon the activities of Western Titanium. A majority shareholding interest in Western Titanium was established in 1969. AMC, under the direction of its managing director, Joseph Pinter, embarked on a process of expansion and acquisition of other mineral sands producers along the coast of northern New South Wales and into Queensland, including dredge-mining activities, initially on South Stradbroke Island and then on North Stradbroke Island. The main products were rutile and zircon. The east-coast ilmenites had a high chrome content and, as such, had limited commercial application. Rutile was used in an array of applications, including for the manufacture of titanium metal and for welding, although the main use was as a feedstock for the manufacture of pigment used in the production of paint. Zircon was used in refractory applications, including the lining of blast furnaces used in steel making, as well as in ceramic manufacture and a range of more specialised uses.

The major trend influencing the industry was the advent of pigment production using the chloride process. While largely initiated by the United States pigment producer, Du Pont, other pigment producers had or were seeking to adopt the chloride process. On the west coast of Australia, Western Titanium had based its initial business, in the late 1950s and early 1960s, on the supply of sulphate ilmenite that, with its low chrome content, was an ideal feedstock for the then dominant sulphate pigment production industry. The advent of chloride pigment production created a potential issue in terms of the ability of the Western Australian producers, of which Western Titanium and Westralian Oil (to become

64 ibid., p. 5. 
Westralian Sands in 1968) were the largest, to supply this emerging sector. More generally, there was also the issue of the continued availability of sufficient rutile, or an alternative product, to meet the increasing demands of chloride pigment producers. The mineral sands producers in Western Australia had access to only limited amounts of rutile in the assemblage of ore bodies. The solution was to seek to beneficiate or upgrade ilmenite to a product with a higher titanium dioxide content that could be used for chloride pigment production. In this regard, Western Titanium was the pioneer in undertaking research and small-scale experimentation to upgrade ilmenite.

AMC had taken an active role in the first half of the 1960s in acquiring smaller mineral sands producers and had established a dominant position as an Australian producer of rutile and zircon. Its operations, typically dredge mining on the forefront of beaches, were conducted at numerous locations in New South Wales. The process of acquiring other producers continued, albeit on a lower scale, in the second half of the 1960s. In 1967, the decision was made to merge AMC with Wyong Minerals, the latter company with dredge-mining operations at Lake Munmorah in New South Wales. ${ }^{65}$

AMC expanded its operations on South Stradbroke Island with the construction of a large dredge and associated concentrating plant, which were commissioned in 1968. The operation maintained the company's position as the largest single producer of rutile and zircon sand in Australia, and for that matter the world'. ${ }^{66}$ In 1969, AMC acquired all of the issued capital of TAZI, a company majority owned by Rio Tinto that was undertaking mining of rutile and zircon on North Stradbroke Island. ${ }^{67}$ This acquisition was associated with a loan advanced by CGFA. The acquisition provided AMC with access to ore reserves and mining equipment on North Stradbroke Island, supplementing its position on South Stradbroke Island. Expansions occurred elsewhere along the east coast and AMC continued to flourish.

65 The leases were adjacent to Lake Munmorah, an area of 760 acres tested by Wyong Alluvials. Wyong Alluvials also held 67.5 per cent of the issued capital of Eastern Titanium Corporation and an interest in the proceeds from the agreement between that company and Coffs Harbor Rutile NL.

66 Associated Minerals Consolidated Limited, 'Chairman's Address Presented to Shareholders at the Sixteenth General Meeting of the Company', 12 September 1968, p. 1, UMA, AW Muddyman Collection, 1995.0041, Unit 96.

67 Associated Minerals Consolidated Limited, 'Notice to Stock Exchange', 20 March 1969, UMA, JB Were and Son, 2000.0017, Unit 611. 

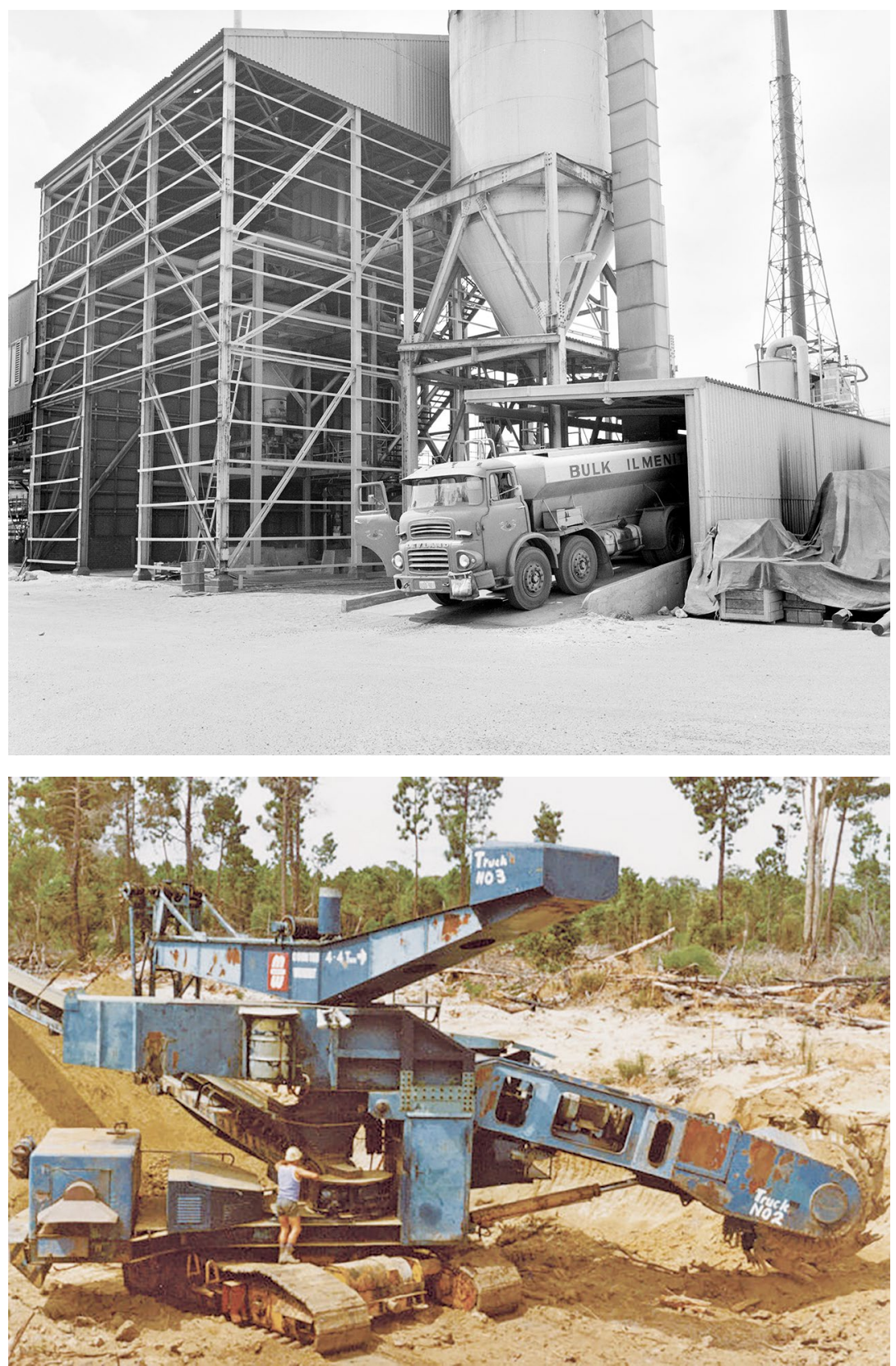

Figures 38 and 39. Western Titanium's operations, Capel, south-west, Western Australia.

Sources: NAA, A1200, L92729, and Iluka Resources archives. 
In 1969, CGFA acquired an interest in Western Titanium. CGFA had already considered the acquisition of Western Titanium's neighbour, Westralian Sands, in the south-west of Western Australia, and held a sufficient shareholding in this company to have an employee of CGFA appointed as a director to its board. However, Western Titanium was viewed as a more suitable means to pursue the implementation of ilmenite upgrading technology. By 1969, the situation for CGFA in terms of acquiring a controlling interest in Western Titanium had 'become quite critical' in the context of the apparent success of its beneficiation process and an offer made by a United States company for both shares in Western Titanium and a longer-term offtake agreement. ${ }^{68}$ Sidney Segal, an executive director of CGFA, held discussions with Consolidated Gold Fields in London and was authorised to match the offer for Western Titanium by the United States company. ${ }^{69}$ A CGFA board meeting minute in 1969 recorded:

In view of the great importance of the upgrading of ilmenite, C.G.F.A. should use every effort, to acquire the Western Titanium process but also ... should be prepared to take up a commanding position in ilmenite, in view of once the fact that the ilmenite upgrading process is proved to be viable and economical, the future economics of rutile production may be limited. ${ }^{70}$

CGFA acquired a 19 per cent shareholding in 1969, with an offer made to acquire a majority position. While initially rejected, a revised offer was accepted by the board of Western Titanium and by November of that year CGFA's shareholding stood at 61 per cent, later to increase to 85 per cent. Western Titanium became a subsidiary of CGFA. Segal was appointed chairman, after commencing as a director in April 1968. His role was transformed into executive chairman, which he retained until 1976. Western Titanium played an instrumental role, not only in the development of ilmenite upgrading technology, but in the establishment ofCGFA's position in a major new mining province in Western AustraliaEneabba - where large reserves of ilmenite were ideal for use in DuPont's chloride process plants or for upgrading to synthetic rutile.

68 Consolidated Gold Fields of Australia Limited, 'Minutes of Meeting of Directors', 23 July 1969, p. 2, RGCA, Box 12264 .

69 ibid.

70 Consolidated Gold Fields of Australia Limited, 'Minutes of Meeting of Directors', 25 June 1969, p. 2, RGCA, Box 12264. 
The consequences of the expansionary program in the 1960s meant that AMC was producing 125,000 tons of rutile in 1969, compared with 14,000 tons 10 years previously. Zircon production had increased to 110,000 tons from 11,000 tons over the same period. AMC was the largest producer of rutile and zircon, supplying more than 40 types of mineral sands products to 33 countries. Profit after tax of $\$ 1.6$ million in 1969 grew to $\$ 5$ million in 1975 , before retreating in the subsequent years until after the merger with Western Titanium.

The governmental focus on mineral sands mining reflected the increasing environmental and regulatory opposition to mining, both in New South Wales and Queensland. It was a trend that grew in intensity and resulted in restrictions upon AMC's activities in the 1970s and cessation of the company's mining operations on most of the east coast, with the exception of North Stradbroke Island, by the 1980s. In October 1968 the New South Wales Government established the Sim Committee to report on mineral sands mining along the coast of New South Wales. It laid out proposals for one-third of the land designated for mining between Tweed Heads and Port Stephens to be preserved with the remaining areas subject to strict conditions for mining. Within 10 years, in October 1977, the New South Wales Cabinet determined that no further approvals for mineral sands mining within the extended Myall Lakes National Park would be approved. Later that year the New South Wales Planning and Environment Commission gazetted direction orders over extensive areas within the vicinity of existing national parks and nature reserves. Similarly, in Queensland, the Beach Protection Act 1968 presented a direct threat to mining activities on Moreton and Stradbroke Islands.

Mining rehabilitation activities became a more prominent part of the company's reporting and promotional activities, with annual reports, chairman's addresses and other materials making reference to the amount of land rehabilitated and the quality of the work undertaken. Pinter became an advocate for the industry's interests and encouraged a program of progressive rehabilitation of areas affected by mineral sands mining along the New South Wales coast. The result was that large areas were restricted from mining; reserves of both zircon and rutile were sterilised, restricting mining plans in new areas, and also truncating the life of some operations. 
CGFA's involvement in Western Australia, through Western Titanium, provided a bulwark against the restrictions on its east-coast mineral sands business and an entry into ilmenite upgrading. Western Titanium had undertaken pilot plant work for the upgrading of ilmenite in the early 1960s, which led to a feasibility study for a larger-scale plant. By the end of 1967 the decision was made to construct a 'semi-commercial' plant. The plant, with a capacity of 10,000 tons per annum, was commissioned in Capel in 1968. Despite considerable experimentation and adjustments to plant settings, by 1969 a sufficient tonnage of the new product had been produced to enable customers to trial it in their plants. ${ }^{71}$ Customer reports were encouraging and demonstrated that the material could be processed in chloride pigment plants. In the early 1970 s various modifications were trialled and the plant was placed on a commercial operating basis from January 1971. In 1974, a larger plant was commissioned with a nominal capacity of 30,000 tons per annum. The development and marketing of an upgraded ilmenite product, referred to as synthetic rutile from 1976, transformed the product offering and financial characteristics of Western Titanium.

By the early 1970s, the original high-grade deposits held by Western Titanium, near Capel, were nearing the end of their economic life. While mining was transferred to a new set of deposits, these were marked by lower heavy-mineral content, as well as an increase in indurated material and a higher clay content. In 1975, mining and production challenges were associated with low-grade ore recovery, exacerbated by a shortage of water. A downturn in the pigment market reduced demand for ilmenite and meant that product had to be stockpiled. The cancellation and deferment of orders was, according to Segal, 'assuming significant proportions. ${ }^{72}$ This, and the demand for higher-grade titanium dioxide feedstocks, such as rutile for the chloride market, led to lower ilmenite production. The mining conditions at Capel also prompted the company to evaluate exploration opportunities in other areas. Eneabba, 196 kilometres north of Perth, would be one of the areas.

71 Western Titanium NL, Annual Report 1970 and Notice of Meeting, p. 5.

72 Consolidated Gold Fields Australia Limited, 'Minutes of Meeting of Directors', 23 April 1975, p. 2 and 28 May 1975, p. 3, RGCA, Box 12246, RGC 11588. 
The early years of the 1970s were challenging for CGFA's mineral sands interests. For AMC, revenues and profitability declined for three successive years to 1973. Lower rutile demand in 1971 and 1972 led to 150 employees in the company being retrenched. Production was lowered and an intensive cost reduction program implemented. The strengthening in the Australian dollar, while favourable in terms of the prices received, caused the company to be concerned at the increasing vulnerability of its products to substitutes or alternative sources of supply, including the planned development by others of Eneabba production in Western Australia, as well as that from Sierra Leone and Richards Bay Minerals in South Africa. ${ }^{73}$ Operating conditions in 1974 and 1975 improved, with markets for products strengthening, enabling additional mining plant capacity to be brought into production. Despite the challenges the company was facing, with the undermining of its east-coast business by reserve depletion and government restrictions, profitability in 1975 and 1976 were the highest the company had recorded. While issued equity had increased threefold since the mid-1960s, the return on equity was above 25 per cent.

On the Sunday evening of 22 November 1971, Segal, the chairman of Western Titanium, received a telephone call in Sydney from Peter Nairn, managing director of Western Titanium. Nairn was at Eneabba and had observed a pegging frenzy, much of it conducted by local farmers, for ground considered to be prospective for mineral sands. He advised Segal of the resource potential of the area and the need for Western Titanium, and in effect CGFA, to move quickly to capture some of the opportunity. The following day Segal received a follow-up telex, outlining the potential of the Eneabba district. The telex read:

Have examined most significant deposit of heavy mineral in Eneabba area ... Area being pegged rapidly by, among others, Allied Minerals, Mining Advisors, Ilmenite Pty Ltd and individuals from local area and Perth. In view of pegging rush consider that WTNL [Western Titanium NL] should tie up part of the area at least by immediate negotiations with claim applicants, and then initiate further prospecting in general area. Can initiate discussions with applications of approximately 8000 acres of mineral bearing ground which has potential of

73 Associated Minerals Consolidated Limited, 'Chairman's Address Presented to Shareholders at the Twentieth General Meeting of the Company held on 5th October 1972'; Associated Minerals Consolidated Limited, 'Chairman's Address Presented to Shareholders at the Twenty-first General Meeting of the Company held on 4th October1973', UMA, JB Were and Son, 2000.0017, Unit 611. 
Ilmenite 7,000,000 tons

Zircon 6,000,000 tons

Leucoxene 4,000,000 tons

Rutile 2,000,000 tons

Negotiations extremely sensitive for a number of reasons including reluctance of possible vendors to associate with CGFA. They consider that pressure could be brought to bear to restrict rutile production because of upgrade commitments ... potential of area most impressive ... Interest being shown by other companies is a measure of real potential of the area and this must be considered in relation to future WTNL operations. ${ }^{74}$

Segal was 'determined to go to Perth as soon as possible to investigate the matter on the spot'. ${ }^{75}$ There followed a convoluted process whereby Western Titanium struck an arrangement with Jim Adamson, part of a farming syndicate involving himself, Tony Freebairn and Jerry Hayes, that had been involved in pegging tenements at Eneabba. The arrangement with Adamson provided Western Titanium with access to an extensive tenement holding and, with it, the potential to participate in production from a new mineral sands province. However, the arrangement struck with Adamson was contended by Freebairn and Hayes not to be binding. They had also established an arrangement with another company-Allied Minerals_ with mining aspirations at Eneabba. There followed a protracted legal dispute, with the position of Freebairn and Hayes, on behalf of Allied Minerals, upheld in the Supreme Court of Western Australia. Western Titanium challenged this ruling in the High Court, with its appeal upheld. This ruling, in turn, was challenged by Allied Minerals in the Privy Council. In 1973 the Privy Council declined to hear Allied Mineral's appeal, endorsing Western Titanium's rights to the tenements. With this, Western Titanium could proceed with the development of its interests at Eneabba. ${ }^{76}$

Throughout the period of the legal dispute, Western Titanium had made overtures to Allied Minerals, whose partner was Du Pont, the United States pigment producer, for a possible merger of interests. ${ }^{77}$ This was not to occur at this stage. Instead, Western Titanium proceeded with its own development plans at Eneabba in the early 1970s. This resulted in the first

\footnotetext{
74 Telex for Segal from Nairn, 23 November 1970, RGCA, Box 12612, RGC 6500.

75 Eneabba Statement by SL Segal, 25 May 1971, RGCA, Box 12612, RGC 6500.

76 A review of the establishment of CGFA's position in the Eneabba mineral sands province is available in Porter, Below the Sands, pp. 81-95.

77 Consolidated Gold Fields Australia Limited, 'Minutes of Meeting of Directors', 26 September 1973, RGCA, Box 12248, RGC 11576.
} 
commercial production in 1974 , although with persistent commissioning problems during a period of severe downturn in mineral sands markets. Meanwhile, two other parties, Jennings Industries and Allied Minerals, had developed their own mineral sands operations at Eneabba.

The establishment of Western Titanium's position at Eneabba, along with the development of synthetic rutile, represented two of the most important developments for the company and of the mineral sands industry in Australia. For CGFA, it enabled the reliance on east-coast deposits and the maturing south-west Western Australian deposits-in the context of the transformation of the production base and product requirements of the main pigment customer base- to be largely supplanted by production from Eneabba. It also established the logic for the merger, or in effect takeover in 1976, at the behest of CGFA, of Western Titanium by AMC.

AMC and Western Titanium operated until 1976 as separate subsidiaries of CGFA. While the geographical separation of their operations provided some differentiation in their activities, the reality was that their product offerings were similar, and often in competition. While Western Titanium was making advances in the process to beneficiate ilmenite, AMC harboured similar ambitions and pursued its own development work. It became apparent that this duality of interests, particularly during periods of poor market conditions and lower prices, was not sustainable.

Following the merger of AMC and Western Titanium, AMC acquired the two other producers at Eneabba, Jennings Industries and Allied Eneabba. In doing so, AMC, or as it had become, RGC Mineral Sands, established itself as the dominant producer of mineral sands in Australia. The company later undertook mining activities in Florida and Virginia. The technical work on ilmenite beneficiation in the south-west of Western Australia, where two kilns had been constructed, provided the foundation for the development of a further two kilns at Geraldton, Western Australia, for which the Eneabba ilmenite was an ideal feed source.

Mineral sands had become the cornerstone of the CGFA portfolio, with the company establishing a prominent position for its products both in Australia and internationally. However, wider portfolio considerations and CGFA's concerns with its high level of indebtedness through the 1970s led to a review of the continued retention of mineral sands within the portfolio. Aggregating CGFA's mineral sands business with other industry participants was considered, as was the complete divestiture of its mineral sands holdings. 
This text is taken from Consolidated Gold Fields in Australia: The Rise and Decline of a British Mining House, 1926-1998, by Robert Porter, published 2020 by ANU Press, The Australian National University,

Canberra, Australia.

doi.org/10.22459/CGFA.2020.10 